УДК 378.147

https://doi.org/10.33296/2707-0255-11(21)-02

\title{
PARAFIYANOVICH TAMARA
}

Doctor of Pedagogical Sciences, Associate Professor, Associate Professor of the Department Information RadioTechnologies, Belarusian State University of Informatics and RadioElectronics, Minsk, Belarus https://orcid.org/0000-0001-9749-4438

\section{BUSHCHIK ELIZAVETA}

Master student of the Department Information RadioTechnologies, Belarusian State University of Informatics and RadioElectronics, Minsk, Belarus

\section{NOVOSELOV NIKITA}

Students of the Department of Information RadioTechnologies, Belarusian State University of Informatics and RadioElectronics, Minsk, Belarus

\section{ADAPTIVE APPROACH TO CREATING CONDITIONS FOR PRACTICAL SELF-REALIZATION OF FUTURE TEACHER-PROGRAMMERS}

Summary. The article substantiates the relevance of an adaptive approach to creating conditions in the educational process for the practical self-realization of students, considered as the implementation of the educational and research abilities of future teacher-programmers, and the formation of professional competencies. In the modern high-tech world, when digital technologies become the environment for the existence of future specialists with new opportunities for their interactions and the desire to solve problems through IT technologies, one of the trends in the development of the education system is to improve its quality, «... includes adaptive processes». Adaptive processes in the design of educational programs are based on the formation of a digital educational space, the availability of online training, the possibility of organizing mixed training, and building individual educational activities. Adaptive approaches are considered as personification of the practicaloriented component of educational activity, development of value orientations, attitudes, as a person-oriented interaction of a teacher-student and a weak impact, which under certain conditions can give a strong resonance. Adaptive approaches are 
presented as a system of flexible management methods that contribute to the practical realization of the interests, abilities and educational needs of students aimed at forming the basic professional competencies of future teacher-programmers. Adaptive approaches in learning management are considered as the personalization of distance activities, as the process of managing the personal and professional development of students; a process that contributes to the desired learning outcomes; the process of using management impacts. The adaptive interaction between the teacher and the student includes pedagogical support, allows you to focus on the abilities and professional preferences of future teacher-programmers, equalize their opportunities for self-realization, self-organization, self-development and personalize the accumulation of universal and professional competencies. The article notes that the widespread use of adaptive approaches has led to a shift in emphasis in education to the achievement of a practical result in the formation of professional competencies, which are not only the result of training, but also a resource for further quality education, training specialists for independent professional activities, the ability to quickly adapt to new socio-professional challenges and a willingness to study during life.

Key words: adaptive approaches, adaptive interaction, digitalization, practical self-realization, training results, personalization, professional competencies of future teacher-programmers.

Introduction. Our time is a time of «intellectualization caused by the widespread introduction of knowledge and innovation, the spread and introduction of new technologies», the creation of new projects, programs, digital platforms [1, p.18]. State investment in human capital and knowledge is becoming a factor of stability. One of the trends in the development of the world educational space and the vector of the development of the national education system is «... the integration of education, science and production, the development of the system of continuing vocational education» [2, p.4], the implementation of a cluster model for the development of pedagogical education, using clusters as systemically important elements for the development of the system of professional training of teachers [3, p.11]. This study defines the content of an adaptive approach to creating conditions for the practical self-realization of students, considered as the realization of the educational and research abilities of future teacher-programmers and the improvement of the quality of education, since new technologies change the life of a person, professions 
disappear and appear at such a speed that it is impossible to obtain professional competencies for life [4, p.4]. For the life and development of future specialists in the modern high-tech world and the transformation of the labor market «... involuntarily, adaptive processes are included that reorient it to new values and force it to form new... » universal and professional competencies [5].

Topical scientific research and analysis of the problem. Theoretical studies of the professional training of teachers contain a number of trends identified in the works of domestic and foreign authors (A. I. Zhuk, O. L. Zhuk, A. V. Torkhova, I. A Tsarik, G. V. Yelnikova, Z.V. Ryabova, etc.). Researchers identify a problematic field in the professional training of teachers related to the inability of students to integrate pedagogical knowledge, underestimating the socio-psychological characteristics of the person, the lack of skills to apply theoretical knowledge in practice, etc. The solution to these problems is seen in the use of adaptive approaches to managing the training of future specialists by creating conditions for the development of the inner world of the individual, its activity and the need for practical educational and research implementation. Activation of the student's position on mastering the educational program implies the ability of effective selfrealization in the educational process, during pedagogical practice in the specialty, the ability to take initiative, overcome stereotypes, design, create new ways and mechanisms for learning professional and personal experience.

Wording of the objectives of the article. Study of an adaptive approach to learning management with a professional focus, including the creation of a system of conditions, incentives, opportunities for the practical self-realization of students and the formation of basic professional competencies. Application of an adaptive approach to personification of the practical-oriented component of educational activity based on the abilities and educational needs of a particular student, and continuous inclusion of the future teacher-programmer in various types of educational and research activities. 
Presentation of the main materials. It is important for a person to be able to form a personal trajectory of personal and professional development using various forms, training technologies and practically realize abilities. The conditions that provide such opportunities were created when mastering the educational program of higher education of the first level in the direction of the specialty 1-08 01 01-07 «Professional training (computer science)», which provides the qualification of «Teacher-programmer». The main areas of professional activity of a specialist and the choice of the direction of his future activity may be: higher education; technical and vocational secondary education; scientific research and development in the field of technical sciences, in addition, computer programming. The general goals of specialist training include the formation of socio-professional, practical-oriented competence, combining universal, basic professional, specialized competencies [6].

Today, the design and adjustment of BSUIR educational programs is aimed at systematically improving the quality of continuing education by forming a digital educational space, the availability of online training, the possibility of organizing mixed training, and building individual educational trajectories. Digital technologies are not only a tool, but also an environment for students to exist with new opportunities for their interactions. Therefore, one of the features of the influence of digital technologies on the educational activities of students is the formation of digital thinking, that is, the desire and ability to solve a particular problem precisely through modern digital technologies [7]. Future teacher-programmers from users of electronic resources gradually become their creators, their mentality and perception of the picture of the world change, which requires completely different approaches, methods and forms of working with students from the teacher. The use of information technologies in education offers unprecedented opportunities to make education more effective, by developing educational programs, online training, and expanding access to them to a wide number of students. The use of IT technologies, methodological approaches, forms, methods and means allows us to consistently model the social content of the future professional activity of a teacher-programmer, that is, the 
assimilation of theoretical knowledge is «put on the verge» of practical activity, and at the same time the personal and professional development of the student and a systematic approach to the future profession is carried out [8, p.113]. The activities of the teacher are aimed at:

- development and consistent implementation of adaptive approaches in the management of professional-oriented learning;

- creation of programs and methodical instructions for subject matters, on studying scientific and multimedia sources;

- ensuring access to electronic resources, lecture materials, videos;

- personalization of practical-oriented educational activities based on the abilities and educational needs of the student;

- inclusion of the future teacher-programmer in various types of educational and research activities;

- creation of a system of conditions, incentives, opportunities for practical self-realization of students on the basis of real individualization and formation of basic professional competencies;

- pedagogical interaction and pedagogical support for the constructive initiative of students.

During online interaction (consultations, workshops, videoconferences), emerging problem situations, the progress and results of individual tasks, the quality of educational or digital products developed by students are discussed. Creation of a system of the conditions, incentives, opportunities for practical self-realization studying at a basis of real individualization is provided with identification of tendencies of students and their inclusion in different types of educational and research activity: practical realization of knowledge, abilities, skills, experience of activity (as the beginning teacher-trainee, either the developer of the software, or participation in research and laboratory projects), in general in creative educational activity. 
New technologies contribute to the development of innovative learning methods, including personalized learning, facilitate interaction between the teacher and the student, exchange and access to resources, making training more flexible. Personalization of training introduces a different responsibility and awareness in the actions of the teacher and student, in the formulation of educational needs and requests, in the choice of forms and means of their own personal and professional development, and in the design of a personal educational trajectory in educational conditions.

One of the forms of personalization of training is the use of an e-learning system, which has the property of adaptability, which involves adaptation to the actions of the student. The student has the opportunity at a convenient time not only to independently perform theoretical and practical tasks, but also to participate in regular lectures, seminars held on a schedule remotely or online. At the same time, often online events are combined with traditional forms of training. The use of the elearning system increases the effectiveness of the implementation of modern pedagogical methods, such as mixed or «inverted» learning, which assumes that the educational discipline is studied by students independently, and the teacher answers questions, helps to understand and master theoretical material.

Adaptive approaches in learning management are now more relevant than ever. Due to changes in social relations, which are expressed in the complication of the inner world of learners, when stimulus does not always satisfy interests, indirect, soft, adaptive management becomes in demand, providing a slow but confident impact with long-term consequences. Adaptive approaches allow you to personalize practical-oriented educational activities, develop value orientations, attitudes, personal-oriented interaction between the teacher and the student, which brings the young man to certain social norms and forces him to behave like that, and not otherwise; a synergistic paradigm of non-equilibrium is appropriate here: a weak effect under certain conditions can give a strong resonance. The use of a system of flexible training management methods is implemented as a personalization of 
distance activities, as a process of managing the personal and professional development of students; as a process that contributes to the desired learning outcomes; the process of using management impacts. The adaptive interaction between the teacher and the student includes pedagogical support, allows you to focus on the abilities and professional preferences of future teacher-programmers, equalize their opportunities for self-realization, self-organization, self-development and personalize the accumulation of universal and professional competencies.

Interaction is realized by activating the student's position, mastering digital skills and directly involving future specialists in solving professional, personal problems, focusing on treating the student as an independent, responsible subject of his own development. Pedagogical support is a specially organized process of personal and professional interaction between the teacher and students, a process of interested observation.

The educational process in the specialty «Professional training (computer science)», built on the basis of adaptive approaches and teaching methods, the process of soft management of the personal and professional development of students; The process that contributes to the desired learning outcomes is reflected in the level of development of their professional competencies and skills in the:

- planning, systematization of funds, development of scientific and methodological support of the lesson;

- structural, logical and didactic analysis of the content of educational disciplines;

- development of modern methods for conducting training classes;

- to solve pedagogical problems based on the situational approach;

- participation in various types of training and research activities, including in scientific, practical and international conferences;

- interaction in an information and educational environment and joint interactive activities;

- organization of its own activities (self-organization); 
- the ability to think creatively, to take a constructive initiative in an information and educational environment;

- ability of effective self-realization in the educational process, in the course of teaching in the specialty;

- create new ways and mechanisms for learning professional and personal experience.

The formed basic professional competencies allow future teacher-programmers to realize inclinations, abilities, professional interests not only in the educational process of the university, which involves the implementation of course and degree projects in the development of information systems, web applications, websites, but also in the course of pedagogical practice in the specialty, integrate information technologies and theoretical knowledge in the field of pedagogy, psychology, methods of teaching general technical and special disciplines, to get practical experience in their application, acting as teachers-practitioners of computer science. The dominant in obtaining the desired results of training is an adaptive approach that encourages the student to engage in the knowledge of himself and the world around him, self-realization, personal productive activity and allows him to transform his educational, scientific and research activities in accordance with his future professional activity.

Conclusion. It is important to note that the innovative nature of the development of society and the education system has led to the widespread use of adaptive approaches and «... a shift in emphasis in the course of education towards achieving a practical result in the formation of skills for using acquired knowledge to solve various situations in the process of human life» [9]. The application of an adaptive approach in teaching management, personification of the practical-oriented component of educational activity, based on the abilities and educational needs of a particular student, the inclusion of future teacher-programmers in various types of educational and research activities allow you to form and accumulate basic professional competencies. Thus, the formed basic professional competencies of the 
future teacher-programmer are not only a condition, the result of training, but also a resource for further high-quality education, preparation of specialists for independent professional activity, the ability to quickly adapt to new socio-professional challenges and a willingness to study during life.

Further studies of the adaptive approach to create conditions for the practical self-realization of a person are based on pedagogical modeling of educational and research activities of future teacher-programmers.

\section{REFERENCES}

1. Kovalev,__M. M. Cifrovaya ekonomika - shans dlya Belarusi_monogr. / M. M. Kovalev, G. G. Golovenchik. - Minsk: Izd. centr BGU, 2018 - 327 s.

2. Prikaz Ministerstva obrazovaniya Respubliki Belarus ot 29.11.2017 № 742 Konceptualnie podhodi k razvitiyu sistemi obrazovaniya Respubliki Belarus do 2020 goda i na perspektivu do 2030 goda [Elektronnii resurs]. - Rejim dostupa: https://normativka.by/lib/document/76205.

3. Koncepciya razvitiya pedagogicheskogo obrazovaniya v Respublike Belarus na 2015-2020 gg. [Elektronnii resurs] // Nacionalnii institut obrazovaniya. - Rejim dostupa: https://www.adu.by/wp-sontent/uploads/2015/ pedklass/koncepciya.pdf.

4. Universitet 20.35 / ASI. - Ekaterinburg: Izdatelskie resheniya, 2017. - T. 34. $-50 \mathrm{~s}$.

5. Elnikova, G.V. Deyaki pitannya organizaciï Adaptivnogo navchannya v zakladah osviti. Elektronne naukove fahove vidannya «Adaptivne upravlinnya: teoriya i praktika» Seriya «Pedagogika» Vipusk 19 (10), 2020.

6. Obrazovatelnii standart visshego obrazovaniya. Pervaya stupen. OSVO 1_08 01 01-2018. Specialnost 1-08 0101 Professionalnoe obuchenie (po napravleniyam). Utverjden i vveden v deistvie postanovleniem Ministerstva obrazovaniya Respubliki Belarus ot 22.12.2018 g. № 124 .

7. Kosenkov A., Tehnologii vs. koronavirus: vzglyad iz Belarusi [Elektronnii resurs]. - Rejim dostupa: https://eurasia.expert/tekhnologii-vs-koronavirus-vzglyadiz-belarusi/.

8. Parafiyanovich, T. A. Upravlenie processom lichnostnogo i professionalnogo razvitiya buduschih pedagogov_programmistov / T. A. Parafiyanovich // Problemi povisheniya effektivnosti obrazovatelnogo processa na baze informacionnih tehnologii $=$ Problems of improving the efficiency of the educational process based on information technology _ materiali XII Mejdunar. nauch._prakt. konf._Respublika Belarus__Minsk_ 25 aprelya 2019 goda, / redkol.: Yu. E. Kuleshov [i dr.]. - Minsk : BGUIR, 2019. - S. 112 - 116. 
9. Elnikova, G.V. STEM_osvita v konteksti adaptivnogo pidhodu. Elektronne naukove fahove vidannya «Ādaptivne upravlinnya: teoriya i praktika» Seriya «Pedagogika» Vipusk 4 (7), 2018.

\section{REFERENCES}

1. Kovalev, M. M. Tsifrovaya ekonomika - shans dlya Belarusi: monogr. /M. M. Kovalev, G. G. Golovenchik. - Minsk: Izd. tsentr BGU, 2018 - 327 s.

2. Prikaz Ministerstva obrazovaniya Respubliki Belarus ot 29.11.2017 № 742 Kontseptualnye podkhody k razvitiyu sistemy obrazovaniya Respubliki Belarus do 2020 goda i na perspektivu do 2030 goda. [Elektronnyy resurs]. - Rezhim dostupa: https://normativka.by/lib/document/76205.

3. Kontseptsiya razvitiya pedagogicheskogo obrazovaniya $\mathrm{v}$ Respublike Belarus na 2015-2020 gg. [Elektronnyy resurs] // Natsionalnyy institut obrazovaniya. - Rezhim dostupa: https://www.adu.by/wp-sontent/uploads/2015/ pedklass/koncepciya.pdf.

4. Universitet 20.35 / ASI. - Yekaterinburg: Izdatelskie resheniya, 2017. - T. 34. $-50 \mathrm{~s}$.

5. Yelnikova, G. V. Deyaki pitannya organizatsiï Adaptivnogo navchannya v zakladakh osviti. Yelektronne naukove fakhove vidannya «Adaptivne upravlinnya: teoriya i praktika» Seriya «Pedagogika» Vipusk 19 (10), 2020.

6. Obrazovatelnyy standart vysshego obrazovaniya. Pervaya stupen. OSVO 10801 01-2018. Spetsialnost 1-08 0101 Professionalnoe obuchenie (po napravleniyam). Utverzhden $\mathrm{i}$ vveden $\mathrm{v}$ deystvie postanovleniem Ministerstva obrazovaniya Respubliki Belarus ot 22.12.2018 g. № 124 .

7. Kosenkov, A. Tekhnologii vs. koronavirus: vzglyad iz Belarusi [Elektronnyy resurs]. - Rezhim dostupa: https://eurasia.expert/tekhnologii-vs-koronavirus-vzglyadiz-belarusi/.

8. Parafiyanovich, T. A. Upravlenie protsessom lichnostnogo i professionalnogo razvitiya budushchikh pedagogov-programmistov / T. A. Parafiyanovich // Problemy povysheniya effektivnosti obrazovatelnogo protsessa na baze informatsionnykh tekhnologiy = Problems of improving the efficiency of the educational process based on information technology: materialy XII Mezhdunar. nauch.-prakt. konf. (Respublika Belarus, Minsk, 25 aprelya 2019 goda) / redkol.: Yu. Ye. Kuleshov [i dr.]. - Minsk : BGUIR, 2019. - S. 112-116.

9. Yelnikova, G. V. STEM-osvita v konteksti adaptivnogo pidkhodu. Yelektronne naukove fakhove vidannya «Adaptivne upravlinnya: teoriya i praktika» Seriya «Pedagogika» Vipusk 4 (7), 2018. 
Електронне наукове фахове видання «Адаптивне управління: теорія і практика.

\section{ПАРАФИЯНОВИЧ ТАМАРА}

кандидат педагогических наук, доцент, доцент кафедры информационных радиотехнологий

Белорусский государственный

университет информатики и

радиоэлектроники,

г. Минск, Беларусь

\section{БУЩИК ЕЛИЗАВЕТА}

магистрант кафедры информационных радиотехнологий,

Белорусский государственный

университет информатики и

радиоэлектроники,

г. Минск, Беларусь

\section{НОВОСЕЛОВ НИКИТА}

студент кафедры информационных

радиотехнологий,

Белорусский государственный

университет информатики и

радиоэлектроники,

г. Минск, Беларусь

\section{АДАПТИВНЫЙ ПОДХОД К СОЗДАНИЮ УСЛОВИЙ ДЛЯ ПРАКТИЧЕСКОЙ САМОРЕАЛИЗАЦИИ БУДУЩИХ ПЕДАГОГОВ-ПРОГРАММИСТОВ}

\footnotetext{
Аннотация. В статье обоснована актуальность адаптивного подхода к созданию условий в образовательном процессе для практической самореализации обучающихся, рассматриваемой как реализация учебнонаучно-исследовательских способностей будущих педагогов-программистов, и формирование профессиональных компетенций. В условиях современного высокотехнологичного мира, когда цифровые технологии становятся средой существования будущих специалистов с новыми возможностями их взаимодействий и стремлением решать задачи посредством IT-технологий, одной из тенденций развития системы образования является совершенствование его качества, «... включающее адаптивные процессы». Адаптивные процессы в проектировании образовательных программ основаны на формировании цифрового образовательного пространства, доступности онлайн-обучения, возможности организации смешанного обучения, выстраивании индивидуальной образовательной деятельности. Адаптивные подходы рассматриваются как персонификация практико-ориентированной

(C) Українська інженерно-педагогічна академія

(C) ГО «Школа адаптивного управління соціально-педагогічними системами»

(C) Парфіянович Т., Бущик Є., Новосєлов М.
} 
составляющей учебной деятельности, развитие ценностных ориентаций, установок, как личностно-ориентированное взаимодействие преподавательобучающийся и слабое воздействие, которое при определенных условиях может дать сильный резонанс. Адаптивные подходы представлены как система гибких методов управления, способствующих практической реализации интересов, способностей и образовательных потребностей обучающихся, направленных на формирование базовых профессиональных компетенций будущих педагогов-программистов. Адаптивные подходы в управлении обучением рассмотрены как персонализация дистанционной деятельности, как процесс управления личностно-профессиональным развитием обучающихся; процесс, способствующий получению желаемых результатов обучения; процесс использования управленческих воздействий. Адаптивное взаимодействие преподавателя и обучающегося включает педагогическую поддержку, позволяет ориентироваться на способности и профессиональные предпочтения будущих педагогов-программистов, выравнивать их возможности для самореализации, самоорганизации, саморазвития и персонифицировать накопления универсальных и профессиональных компетенций. В статье отмечается, что широкое использование адаптивных подходов обусловило смещение акцентов в образовании на достижение практического результата по формированию профессиональных компетенций, которые являются не только результатом обучения, но и ресурсом дальнейшего качественного образования, подготовки специалистов к самостоятельной профессиональной деятельности, способности быстро адаптироваться к новым социально-профессиональным вызовам и готовности учиться в течение жизни.

Ключевые слова: адаптивные подходы, адаптивное взаимодействие, цифровизация, практическая самореализация, результаты обучения, персонализация, профессиональные компетенции будущих педагоговпрограммистов. 


\section{ПАРАФІЯНОВИЧ ТАМАРА}

кандидат педагогічних наук, доцент, доцент кафедри інформаційних радіотехнологій

\section{БУЩИК ЄЛИЗАВЕТА}

магістрант кафедри інформаційних радіотехнологій,

\section{НОВОСЕЛОВ МИКИТА}

студент кафедри інформаційних радіотехнологій, Білоруський державний університет інформатики та радіоелектроніки, м. Мінськ, Білорусь

\section{АДАПТИВНИЙ ПІДХІД ДО СТВОРЕННЯ УМОВ ДЛЯ ПРАКТИЧНОЇ САМОРЕАЛІЗАЦЇ̈ МАЙБУТНІХ ОСВІТЯН-ПРОГРАМІСТІВ}

Анотація. У статті обгрунтована актуальність адаптивного підходу до створення умов в освітньому процесі для практичної самореалізації учнів, що розглядається як реалізація навчально-науково-дослідних здібностей майбутніх педагогів-програмістів, та формування професійних компетенцій. В умовах сучасного високотехнологічного світу, коли цифрові технології стають середовищем існування майбутніх фахівців 3 новими можливостями їх взаємодій та прагненням вирішувати завдання за допомогою IT-технологій, однією з тенденцій розвитку системи освіти є вдосконалення іiі якості, «... включає адаптивні процеси». Адаптивні процеси в проектуванні освітніх програм засновані на формуванні цифрового освітнього простору, доступності онлайн-навчання, можливості організації змішаного навчання, вибудовуванні індивідуальної освітньої діяльності. Адаптивні підходи розглядаються як персоніфікація практико-орієнтованої складової навчальної діяльності, розвиток ціннісних орієнтацій, установок, як особистісно-орієнтована взаємодія викладач-навчальник та слабкий вплив, який за певних умов може дати сильний резонанс. Адаптивні підходи представлені як система гнучких методів управління, що сприяють практичній реалізації інтересів, здібностей та освітніх потреб учнів, спрямованих на формування базових професійних компетенцій майбутніх педагогів-програмістів. Адаптивні підходи в управлінні навчанням розглянуті як персоналізація дистанційної діяльності, як процес управління особистісно-професійним розвитком учнів; процес, що сприяє отриманню бажаних результатів навчання; процес використання управлінських впливів. Адаптивна взаємодія викладача та навчального включає педагогічну підтримку, дозволяє орієнтуватися на здібності та професійні уподобання майбутніх 
педагогів-програмістів, вирівнювати їх можливості для самореалізації, самоорганізації, саморозвитку та персоніфікувати накопичення універсальних та професійних компетенцій. У статті зазначається, що широке використання адаптивних підходів зумовило зміщення акцентів в освіті на досягнення практичного результату щодо формування професійних компетенцій, які $є$ не лише результатом навчання, а й ресурсом подальшої якісної освіти, підготовки фахівців до самостійної професійної діяльності, здатності швидко адаптуватися до нових соціально-професійних викликів та готовності навчатися протягом життя.

Ключові слова: адаптивні підходи, адаптивна взаємодія, цифровізація, практична самореалізація, результати навчання, персоналізація, професійні компетенції майбутніх педагогів-програмістів. 